\title{
WSPÓŁPRACA UKRAIŃSKICH, SŁOWEŃSKICH I CHORWACKICH KONSERWATYSTÓW W WIEDEŃSKIEJ RADZIE PAŃSTWA WE „WSPOMNIENIACH Z MOJEGO ŻYCIA" OŁEKSANDRA BARWIŃSKIEGO (1897-1904)
}

\section{Roman Lechniuk}

(1) http://orcid.org/0000-0003-2382-3459

Politechnika Lwowska (Ukraina)

\author{
ABSTRACT \\ COOPERATION OF THE UKRAINIAN, SLOVENIAN AND CROATIAN \\ CONSERVATIVES IN THE IMPERIAL COUNCIL IN OLEKSANDR \\ BARVINSKY'S “MEMORIES OF MY LIFE” (1897-1904)
}

The article analyzes the history of cooperation between the Ukrainian group of the Viennese Imperial Council members and Slovenian and Croatian conservative politicians within the Slavic Christian People's Union and "Slavic Center" factions on the basis of a memoir of Oleksandr Barvinsky, one of the leading Ukrainian politicians at the turn of the $19^{\text {th }}$ and $20^{\text {th }}$ centuries. The author studies the reasons that inspired Barvinsky to such a cooperation, and to what extent it was part of the ideological principles of himself and of the Ukrainian Christian-social movement, which he created and headed in Galicia. The main stages of the activity of both factions are examined as well as factors that influenced their effectiveness. Despite their considerable potential and local successes, the parliamentary clubs created by the conservative Ukrainians, Slovenes and Croatians could not fully realize their agenda. The main reasons, widely considered in the memoir, were a deep political crisis in Cisleithania and, as a consequence, the parliament's inability to take constructive action, as well as the decline of political influence and popularity of Ukrainian conservatives and Oleksandr Barvinsky himself.

Keywords: Oleksandr Barvinsky, Ukrainian-Slovenian-Croatian cooperation, the Imperial Council, Slavic Christian People Union, "Slavic Center", conservatism, Cisleithania.

Słowa kluczowe: Ołeksandr Barwiński, współpraca ukraińsko-słoweńsko-chorwacka, Rada Państwa, Słowiański Związek Chrześcijańsko-Ludowy, „Centrum Słowiański”, konserwatyzm, Przedlitawia. 
Idea słowiańska w różnych jej wariantach zajmowała zauważalne miejsce w intelektualnym obszarze słowiańskich narodów w XIX i na początku XX wieku. W przypadku historii ukraińskiego ruchu narodowego w Galicji ideę słowiańską utożsamiano z ruchem rusofilskim. Rusofile głosili historyczną i kulturalną jedność Słowian wschodnich na gruncie spuścizny średniowiecznej Rusi Kijowskiej ${ }^{1}$. Chociaż rusofile byli niezwykle ważnym, a niemal do końca XIX wieku także dominującym, kierunkiem myśli narodowej i społecznej wśród Ukraińców Galicji, to nie byli oni jedynymi, którzy przykładali uwagę do szukania wspólnoty interesów wśród Słowian. Całkowicie odmienną od rusofilskiej koncepcję obopólnie korzystnego współdziałania między Słowianami wcielał w życie przedstawiciel konserwatywnej części ruchu galicyjskich narodowców ukraińskich - Ołeksandr Barwiński (1847-1926)².

Barwiński w ciągu swojego życia dał się poznać jako polityk, pedagog, organizator licznych naukowych i kulturalnych instytucji. Był jednym z inicjatorów przekształcenia towarzystwa literackiego (Towarzystwa im. Szewczenki) w stowarzyszenie naukowe, działające pod nazwą Naukowe Towarzystwo im. Tarasa Szewczenki, a następnie został jego kierownikiem w latach 1892-1897. Żyjąc w czasach fundamentalnych zmian ustrojowych w monarchii habsburskiej, był deputowanym Sejmu Krajowego galicyjskiego (1894-1904), izby posłów (1891-1907) i izby panów (1917-1918) Rady Państwa, a w latach 1918-1919 delegatem Ukraińskiej Rady Narodowej i sekretarzem państwowym do spraw religii i edukacji w pierwszym rządzie Zachodnioukraińskiej Republiki Ludowej. Barwiński również - aktywny popularyzator ukraińskiej historii, redaktor serii wydawniczej pt. Ruśka istoryczna biblioteka - jako jeden z pierwszych zaczął stosować termin „Ukraina-Ruś” zamiast dawniejszego „Ruś”3.

W działalności politycznej Barwiński przede wszystkim odznaczył się jako lider ukraińskiego ruchu chrześcijańsko-społecznego - konserwatywnego środowiska, które powstało wskutek rozłamu galicyjskich narodowców po niepowodzeniu polityki polsko-ukraińskiego porozumienia w latach 1890-1894 - tak zwanej „nowej ery”4. W odróżnieniu od większości narodowców, których liderem był Julijan Romanczuk, Barwiński nalegał na przedłużenie pragmatycznej, alboż „realnej”s polityki. Polegać

1 O rusofilach galicyjskich oraz ich koncepcjach: A.В. Вендланд, Русофіли Галичини. Українські консерватори між Австрією і Росією, 1818-1915, Львів 2015; Р. Лехнюк, На порозі модерного світу. Украӥнські консервативні середовища в Галичині у першій чверті ХХ століття, Львів 2019, s. 69-82.

2 О. Аркуша, Барвінський Олександр Григорович [w:] Енииклопедія історії України, ред. В. А. Смолій [et al.], т. 1, иїв 2003, s. 189; I. Чорновол, Тягар прагматизму, або Олександр Барвінський у світлі сучасності [w:] О. Барвінський, Спомини з мого життя, т. 1, упор. А. Шацька, О. Федорук, ред. Л. Винар, І. Гирич, Київ 2004, s. 17-35; Р. Лехнюк, Дилеми українського консерватора - приклад Олександра Барвінського [w:] Матеріали III. Міжнародної науково-практичної конференції „Тернопіль і Тернопілля в історії та культурі України і світу (від найдавніших часів до сьогодення)", ред. І.С. Зуляк, Тернопіль 2017, s. 66-72.

3 I. Чорновол, Галицькі війни за історію, http://zbruc.eu/node/5444 (dostęp: 19 V 2019).

4 Więcej o ugodzie i roli Barwińskiego: D. Maciak, Próby porozumienia polsko-ukraińskiego w Galicji w latach 1888-1895, Warszawa 2006; І. Чорн ов ол, Польсько-украӥнська угода 1890-1894 pp., Львів 2000.

5 Jeden fragment swoich Wspomnień... Barwiński rozpoczyna od słów Otto von Bismarcka: „Politik ist die Kunst des Möglichen” („Polityka jest sztuką tego, co możliwe”). Інститут літератури ім. Т.Г. 
ona miała na poszukiwaniu możliwości dla porozumienia (dopuszczalnego z punktu widzenia wartości i zasad) zarówno z elitami polskimi w Galicji, jak i wiedeńskimi kołami rządowymi dla otrzymania maksymalnie szerokich możliwości dla kulturalnego i, w konsekwencji, narodowo-politycznego rozwoju społeczności ukraińskiej. Opozycyjną politykę Romanczuka uważał Barwiński za pozbawioną perspektyw, ponieważ jego zdaniem Ukraińcy w Austro-Węgrzech nie osiągnęli jeszcze wystarczającego poziomu rozwoju społecznego, a co za tym idzie, znaczenia politycznego koniecznego do efektywnej opozycji ${ }^{6}$. Jako przeciwwagę Barwiński propagował zapożyczoną w znacznej mierze od krakowskich stańczyków koncepcję ,pracy organicznej" - powszechnej i codziennej pracy nad podwyższeniem oświatowego, narodowego i politycznego poziomu społeczeństwa ukraińskiego zamiast marnotrawienia jego sił na nieefektywne manifestacje. Takie poglądy były przyczyną stałej krytyki i oskarżeń Barwińskiego ze strony innych ukraińskich politycznych sił Galicji o propolskie sympatie i ,ugodowość"?.

Chociaż prowadzony przez Barwińskiego ruch chrześcijańsko-społeczny w końcu zaznał niepowodzenia i przed I wojną światową nie odgrywał już zauważalnej roli w polityce ukraińskiej w Galicji, jego historia zawiera sporo ważnych stronic. Godne uwagi są szczególnie podejmowane przez Barwińskiego próby prowadzenia ,realnej” polityki. Jednym z najważniejszych osiągnięć tego środowiska było nawiązanie ścisłej współpracy w wiedeńskiej Radzie Państwa ze słoweńskimi i chorwackimi konserwatystami katolickimi w latach 1897-1904. Jej skutkiem było sformowanie przez tychże posłów wspólnych klubów parlamentarnych: Słowiańskiego Związku Chrześcijańsko-Ludowego (dalej: SZChL, 1897-1900) i Centrum Słowiańskiego (1901-1904). Ta współpraca była prawie niedostrzegana przez ukraińskich historyków, z wyjątkiem Andrija Klisza i Romana Lechniuka ${ }^{8}$. Częściowo problem ten studiował austriacki historyk Harald Binder ${ }^{9} \mathrm{i}$ badacze słoweńscy: Vasilij Melik ${ }^{10}$ i Boris Radosavljevič ${ }^{11}$.

Współdziałanie ukraińskich, słoweńskich i chorwackich konserwatystów w parlamencie wiedeńskim dosyć intensywnie naświetliła prasa (w przypadku ukraińskim czasopismo „Rusłan”). Ponadto w zasobach Centralnego Państwowego Archiwum

Шевченка НАН України, Відділ рукописних фондів і текстології, м. Київ (dalej: ІЛ НАН), ф. 135: О.Г. Барвінський, спр. 30: О.Г. Барвінськи й, Спомини з мого життя, ч. 6, 3. 29, nienumerowany arkusz przed арк. 1.

6 Львівська національна наукова бібліотека ім. В. Стефаника (dalej: ЛННБУ), ф. 11: О.Г. Барвін ські, спр. 5387, п. 332, арк. 1-2: Wystąpienie O. Barwińskiego na posiedzeniu organizacyjnym towarzystwa „Ruska Hromada” we Lwowie, 1903.

7 Przykładem krytyki ze strony narodowców może być: Наші християнські суспільники, Львів 1910.

А. Кліш, Р. Лехнюк, Співпраця слов'янських депутатів християнсько-суспільного напряму в австрійській Державній раді наприкіниі XIX - на початку XX cm. (за украӥнськими джерелами), „Проблеми слов'янознавства” (Львів) 2016, вип. 65, s. 167-177.

9 H. Binder, Galizien in Wien. Parteien, Wahlen, Fraktionen und Abgeordnete im Übergang zur Massenpolitik, Wien 2005.

10 V. Melik, Slovenci v Državnem zboru 1893-1904, ,Zgodovinski časopis”, letnik 33, 1979, št. 1, s. 49-66.

11 B. Radosavljevič, Katoliška narodna stranka in Hrvati v letih 1897-1903, „Zgodovinski časopis", letnik 48, 1994, št. 3, s. 335-351. 
Historycznego Ukrainy we Lwowie znajdują się protokoły obrad frakcji SZChL za lata 1897-1900. Niemożliwe jednak jest pełne odtworzenie historii tego współdziałania bez wykorzystania przechowywanych w Instytucie Literatury im. T. Szewczenki Narodowej Akademii Nauk Ukrainy w Kijowie niedokończonych wspomnień Ołeksandra Barwińskiego, który, oprócz tego, że niezmiennie stawał na czele ukraińskiej grupy w SZChL i Centrum Słowiańskiego, był również jednym z kierowników tych frakcji.

„Wspomnienia z mojego życia” Barwiński zaczął pisać jeszcze w czasie aktywnej działalności politycznej przed I wojną światową i prowadził pracę nad nimi aż do swojej śmierci w grudniu 1926 roku (rękopis urywa się na wydarzeniach roku 1908). Pamiętniki te są przypuszczalnie najobszerniejszym ukraińskim pamiętnikiem dotyczącym politycznych, kulturalnych i innych procesów w Galicji. Rękopisy, które obejmują wydarzenia z lat 1888-1908 (bez opublikowanej jeszcze za życia autora części o wydarzeniach do roku 1888), liczą około 6000 arkuszy papieru z licznymi dodatkami ${ }^{12}$. Zapoznanie się ze „Wspomnieniami...” Barwińskiego pozwala docenić sumienność i ugruntowane podejście ich autora do procesu pisania. Na przykład jeden z fragmentów „Wspomnień...” w całości opiera się na wspomnianych już protokołach obrad SZChL. Nie dziwi zatem, że historia współpracy prowadzonej przez Barwińskiego grupy polityków ukraińskich w Radzie Państwa ze słoweńskimi i chorwackimi konserwatystami została naświetlona we „Wspomnieniach...” szczegółowo, co więcej, zawierają one prócz opisu wydarzeń także autorską ocenę różnych aspektów kształtowania, organizacji i działalności obu wspomnianych wcześniej wspólnych klubów parlamentarnych na tle ówczesnych procesów politycznych i społecznych. Fakt ten sprawia, że przedstawiony w pamiętnikach pogląd Barwińskiego na współpracę wymaga oddzielnej i dokładnej analizy.

Przesłanką do podjęcia współpracy przez Ukraińców, Słoweńców i Chorwatów w Radzie Państwa stały się wybory parlamentarne na początku 1897 roku. W przeddzień kampanii wyborczej Barwiński i jego konserwatywna grupa narodowców ostatecznie oderwała się od większości ruchu narodowego z powodu niezgodności poglądów w zakresie obranej taktyki politycznej (kroplą, która przebrała miarę, było podjęcie przez narodowców współpracy z rusofilami, co dla Barwińskiego i jego towarzyszy było niedopuszczalne). Oficjalnie rozłam dokonał się 14 października 1896 roku poprzez założenie Katolickiego Związku Rusko-Ludowego (dalej: KZRL), który był pierwszą próbą zorganizowania przez Barwińskiego własnej organizacji politycznej. Chociaż sam projekt KZRL w ogóle nie odniósł sukcesu, w wyborach 1897 roku do Rady Państwa weszło sześciu deputowanych, którzy byli jego członkami albo wyznawali zbliżone go niego poglądy: lider środowiska Ołeksandr Barwiński, Anatol Wachnianyn, Iwan Grobelski, Kornyło Mandyczewski, Modest Karatnicki i Ksenofont Ochrymowicz.

Oni, a także przedstawiciel Bukowiny Iwan Winnicki, utworzyli 27 marca 1897 roku Klub Ruski (do którego nie weszli trzej inni ruscy deputowani: Danyło Taniaczkewicz, Roman Jarosewicz i Teofil Okunewski). Natomiast już 2 kwietnia

12 Л. Винар, І. Гирич, Вступне слово [w:] О. Барвінський, op. cit., т. 1, , s. 11-14. 
tegoż roku Barwiński zawiadamiał swoją żonę o udanym zakończeniu rokowań Klubu Ruskiego ze słoweńskimi i chorwackimi konserwatystami katolickimi na temat utworzenia wspólnej frakcji, do której ostatecznie weszło siedmiu ukraińskich, 16 słoweńskich, 11 chorwackich posłów, a także jeden przedstawiciel czeskiego ruchu katolickiego z Moraw, przyszły biskup Ołomuńca, Antonín Cyril Stojan ${ }^{13}$. Frakcja mogła być i liczebniejsza, ponieważ rokowania toczyły się jeszcze z dwoma politykami serbskimi, lecz na przeszkodzie stanęły nieporozumienia między Serbami i Chorwatami. Barwiński pisał: „Kiedy Rusini, Słoweńcy, Chorwaci i Serbowie zebrali się na wstępną naradę, odbyła się między Chorwatami i Serbami tak zapalona kłótnia, że okazał się związek z Serbami niemożliwy. Chorwaci bronili swoich praw historyczno-państwowych, z którymi Serbowie nie mogli się pogodzić"14.

Nowo utworzony ukraińsko-sloweńsko-chorwacki SZChL miał trzech przewodniczących, z których każdy reprezentował jeden z narodów. Ze strony ukraińskiej funkcję tę pełnił Barwiński, na czele Słoweńców stanął znany ówcześnie polityk słoweński Ivan Šušteršič ${ }^{15}$, a Chorwatów reprezentował ówczesny przewodniczący sejmu dalmatyńskiego Kajetan Bulat. Ich przewodnictwo nad Związkiem było rotacyjne, zmieniali się co miesiąc. Pomagało im czworo wybranych przedstawicieli, którzy, razem z czynnym danego miesiąca przewodniczącym, tworzyli zarząd związku. Każda z grup narodowych wewnątrz SZChL zachowywała autonomię i oprócz walnych zgromadzeń frakcji przeprowadzała również swoje własne obrady ${ }^{16}$. Złożony z 12 paragrafów statut zobowiązywał każdego członka klubu do podporządkowania się decyzjom walnych zgromadzeń frakcji, a w szczególności do głosowania według ich decyzji i uczestnictwa we wszystkich obradach (każda absencja miała być usprawiedliwiona). Każdy członek miał ponadto prawo wnosić poprzednio zaakceptowane przez frakcję projekty ustawy na forum Rady Państwa albo też zapytania do rządu ${ }^{17}$. Taka wyraźnie reglamentowana i zdyscyplinowana działalność w parlamencie pozytywnie wpływała, w ocenie Barwińskiego, na polityków ukraińskich. Barwiński opisuje ją jako wzór porządku i hierarchii politycznej ${ }^{18}$.

W płaszczyźnie ideologicznej SZChL był klubem konserwatywnym, który stawiał sobie zasadniczo dwa główne cele. Pierwszym było, zgodnie z cytowanym we „Wspomnieniach...” programem frakcji, „dążyć do polepszania życia publicznego w aspekcie religijnym, kulturalnym, socjalnym i ekonomicznym na gruncie pozytywnie chrześcijańskim" ${ }^{\prime 19}$. Duży akcent został położony na sprawy społeczno-ekonomiczne, albowiem konserwatyści odczuwali szczególne zagrożenie ze strony nowych ideologii, przede wszystkim socjalistycznej. W programie zwracano uwagę

13 ІЛ НАН, ф. 135, спр. 34: О.Г. Барвінський, Спомини з мого життя, ч. 6, 3. 33, арк. 700-703.

14 Ibidem, арк. 702. Ten i kolejne cytaty w thumaczeniu autora niniejszego tekstu.

15 W 1898 r. Šušteršič złożył mandat poselski. Jego następcą na czele Słoweńców został Franc Povše.

16 ІЛ НАН, ф. 135, спр. 34, арк. 702-703.

17 Ibidem, арк. 707-708.

18 Ibidem, спр. 35: О.Г. Барвінський, Спомини з мого життя, ч. 6, 3. 34, арк. 856-857.

19 Ibidem, спр. 34, арк. 706. 
na potrzebę dokonania reform socjalnych, ale w duchu chrześcijańskim; w pierwszej kolejności chciano polepszyć sytuację robotników przemysłowych i ludności wiejskiej $^{20}$. Nawiązano tym samym do encykliki Rerum novarum papieża Leona XIII, która w znacznej mierze przyczyniła się do tworzenia w Europie ruchów chrześcijańsko-społecznych, takich jak ugrupowania ukraińskie, słoweńskie i chorwackie zrzeszone w SZChL. Przymiotnik ,chrześcijański” w nazwie ugrupowania był uzasadniony nie tylko z powodu programu, ale także z racji, iż na 35 posłów zrzeszonych w klubie aż 12 z nich było osobami konsekrowanymi.

O chrześcijańskim i konserwatywnym charakterze frakcji SZChL i poszczególnych skupionych w nim grup politycznych świadczy również ogłoszenie przez nie jako elementu programu przedwyborczego listu pasterskiego biskupów austriackich, który ukazał się w przeddzień wyborów 1897 roku. Główna treść tego listu to szereg wymogów kierowanych do wyborców, a także program koniecznych dla państwa reform. W liście namawiano do głosowania na kandydatów, którzy byli szczerymi katolikami, bronili autorytetu Kościoła i ogólnie znaczenia religii ${ }^{21}$. Tylko tacy kandydaci mogli - zdaniem biskupów - zmienić niezadowalającą sytuację oświatową po przyjęciu przez liberalną większość w Radzie Państwa w 1869 roku ustawy o odseparowaniu szkoły i Kościoła: „[...] teraźniejsza szkoła ludowa nie daje gwarancji, że wasze dzieci będą wychowane i uczone w duchu katolickim, jej nauka i jej edukacja nie mają na sobie cech wiary katolickiej i życia katolickiego" ${ }^{22}$. Oprócz tego biskupi nawoływali do równouprawnienia narodowego i szacunku wzajemnego między narodami monarchii. Ważnym aspektem listu pasterskiego było zwrócenie uwagi na problemy społeczno-ekonomiczne (pochylenie się nad zagadnieniami socjalnymi, prawna obrona robotników i chłopów, kuratela nad ubogimi, rozwój dobroczynności $)^{23}$. Jednocześnie przestrzegano przed niebezpieczeństwem agitacji socjalistycznej; podkreślano populistyczny i demagogiczny charakter ugrupowań lewicowych ${ }^{24}$.

Drugim celem SZChL była walka o wspomniane w liście biskupów realne, a nie tylko deklaratywne, równouprawnienie wszystkich narodów, w tym przede wszystkim słowiańskich ${ }^{25}$. Zrzeszeni w klubie Ukraińcy, Słoweńcy i Chorwaci odnosili ten punkt do swojej sytuacji politycznej, którą uznawali za niezadowalającą. Ukraińcy domagali się równouprawnienia z Polakami w Galicji, Chorwaci - z Włochami w Dalmacji, a Słoweńcy - z Włochami w Istrii i Niemcami austriackimi w Krainie, Karyntii oraz Styrii. O doniosłości kwestii narodowej w programie SZChL świadczy fakt, że Barwiński i Bulat włączyli się do pracy w komisji, która przygotowywała adres większości parlamentarnej do cesarza. Pod wpływem nalegań przedstawicieli

20 Ibidem.

21 Архиепископи і епископи австрийскі вірним своїх епархій мир, привіт і благословенє $і$ Ісусї Господї нашім, „Руслан”, 16 (28) I 1897, nr 12.

22 Ibidem.

23 „Руслан”, 17 (29) I 1897, nr 13.

24 „Руслан”, 18 (30) I 1897, nr 14.

25 ІЛ НАН, ф. 135, спр. 34, арк. 706. 
SZChL do dokumentu wniesiono punkt o konieczności wcielenia w życie pełnego równouprawnienia wszystkich narodów państwa ${ }^{26}$.

Oprócz wspólnych ideowych zasad na podstawie „Wspomnień...” Barwińskiego można wyróżnić dwa główne motywy, którymi kierowali się członkowie klubu. Pierwszym z nich była chęć uprawiania „realnej polityki”. Dla Barwińskiego było oczywiste, że nieliczna ukraińska reprezentacja nie ma szans stać się czynnikiem wpływowym w parlamencie wiedeńskim, a więc i nie będzie na niej zależało kluczowym graczom przedlitawskiej sceny politycznej. Jeszcze w 1891 roku, gdy Barwiński po raz pierwszy został wybrany do Rady Państwa, zaproponował, by ówczesny Klub Ruski, kierowany wtedy przez Romanczuka, wszedł do klubu Karla Sigmunda von Hohenwarta - jednego z najbardziej doświadczonych i znanych polityków konserwatywnych Przedlitawii. Było to środowisko konserwatywno-klerykalne, które jednoczyło niemieckich konserwatystów, słoweńskich, chorwackich oraz rumunskich parlamentarzystów i było jedną z największych, a więc i bardzo wpływowych, koalicji w Radzie Państwa. Wtedy jednak idea realpolitik nie doczekała się poparcia przez większość ukraińskich posłów, dlatego utworzyli oni odosobnioną frakcję $\mathrm{w}$ parlamencie wiedeńskim ${ }^{27}$. Zdaniem Barwińskiego znaczącą rolę w takiej decyzji odegrały wówczas ambicje osobiste Romanczuka, który chciał zostać liderem własnego klubu parlamentarnego. Uważając taką decyzję za błąd, przywódca ruchu chrześcijańsko-społecznego nawet po ponad 30 latach od czasów tych wydarzeń wypominał innym ukraińskim politykom:

[...] nasze politycznie mało doświadczone społeczeństwo pragnęło utworzyć oddzielny Ruski Klub [...]. A tymczasem czterech Rumunów w licznym klubie przy pomocy wybitnego i wpływowego działacza państwowego, jak hrabia Hohenwart, mieli nieporównywalnie większe znaczenie i zdobyli z jego pomocą o wiele większe sukcesy aniżeli siedmioro posłów ruskich $^{28}$.

W tym kontekście pozytywne dla Ukraińców praktyczne skutki utworzenia SZChL ujawnily się niemal natychmiast po jego powstaniu. Wówczas to wszyscy Słoweńcy i Chorwaci podpisali protest Klubu Ruskiego przeciw nadmiernym, nawet jak na ówczesne realia w Galicji, nadużyciom wyborczym podczas niedawnej kampanii wyborczej do Rady Państwa ${ }^{29}$. Barwiński niejednokrotnie w swoich pamiętnikach podkreślał, że uczestnictwo SZChL dawało Ukraińcom znacznie większe możliwości w parlamencie, w szczególności co do uczestnictwa w komisjach, wybrania do delegacji Przedlitawii na coroczne obrady austro-węgierskie czy nawet presji na premiera oraz członków rządu.

Innym motywem była sytuacja parlamentarna wiosną 1897 roku. Nowo obrana Rada Państwa wyraźnie się różniła od poprzednich kadencji: zaprowadzanie V kurii (głosowania powszechnego) pozwoliło wejść do parlamentu politykom radykalnym, zarówno lewicowym (socjaliści), jak i prawicowym (,wszechniemiecka”

\footnotetext{
26 Ibidem, арк. 778-779.

27 Ibidem, арк. 701.

28 Ibidem, арк. 701-702.

29 Ibidem, арк. 720-722.
} 
partia Georga Schönerera). To istotnie i dość negatywnie zaważyło na zdolności do pracy w izbie posłów. Oprócz tego rozpadła się dawna większościowa koalicja, od uprawiania aktywnej polityki odszedł bowiem sam Karl Hohenwart, wskutek czego doszło do rozpadu jego wielonarodowej frakcji i poszukiwania przez jej byłych członków, w tym Słoweńców i Chorwatów, nowych możliwości. Na porządku dziennym nowego parlamentu było więc pytanie o utworzenie większości w izbie posłów. Przy takiej sytuacji frakcja złożona z 35 deputowanych mogła mieć o wiele większe znaczenie dla uformowania koalicji niż nieliczny Klub Ruski.

Pierwsze podjęte przez premiera Przedlitawii Kazimierza Badeniego próby utworzenia większości parlamentarnej spośród członków Koła Polskiego, Czechów i niemieckich liberałów nie powiodły się ze względu na narastający czesko-niemiecki antagonizm wywołany obiecanymi przez Badeniego nowymi rozporządzeniami językowymi dla Czech i Moraw, które zrównywały język czeski z niemieckim ${ }^{30}$. Sukcesem zakończyła się natomiast próba utworzenia parlamentarnej koalicji z prawicy złożonej przeważnie z konserwatywnych oraz katolickich frakcji: Koła Polskiego, Czechów (młodoczechów i klubu czeskiej szlachty), niemieckiej grupy katolików oraz SZChL. Nowa większość liczyła 222 głosy w 425-osobowej izbie posłów. Oznaczało to, że opuszczenie koalicji przez którąkolwiek frakcję spowodowałoby rozpad całej prawicy. Zdaniem Barwińskiego sytuacja ta okazała się znakomitym zbiegiem okoliczności dla ukraińsko-słoweńsko-chorwackiej frakcji, przecież i ona, mając 35 przedstawicieli, posiadała „złotą akcję” i jej pobyt w składzie koalicji również był poręczeniem istnienia parlamentarnej większości. To zmuszało Polaków, Czechów i niemieckich konserwatystów do liczenia się z postulatami $\mathrm{SZChL}^{31}$. Właśnie z tego powodu - jak zaznaczał Barwiński w pamiętnikach - jego inicjatywa utworzenia wspólnej frakcji okazała się bardzo na czasie, wszak zaledwie w ciągu doby po formalnym zatwierdzeniu SZChL zaczęły się rokowania o utworzeniu prawicowej koalicji32.

Taki początek kadencji parlamentarnej pozytywnie nastrajał zarówno ukraińskich konserwatystów na czele z Barwińskim, jak i jego słoweńskich oraz chorwackich partnerów. Sytuacja w parlamencie szybko się jednak skomplikowała, co w konsekwencji doprowadziło do zakończenia kadencji parlamentu latem 1900 roku. Do tego momentu obrady Rady Państwa były paraliżowane najpierw przez niemiecką, a z czasem także czeską, obstrukcję. Przyczyną kryzysu parlamentarnego stały się wspomniane rozporządzenia językowe Badeniego z 1897 roku. Faktyczne zrównywanie języka czeskiego z niemieckim w Czechach i na Morawach wywołało zażarty opór Niemców austriackich i wzrost popularności wśród nich nacjonalizmu radykalnego, przede wszystkim partii Schönerera.

W rzeczywistości sprzeczności na tle narodowym narastały w monarchii przez całą dekadę. Niepowodzenie ukraińsko-polskiej „,nowej ery” 1890-1894 roku i czesko-niemieckiego porozumienia z 1890 roku, zaostrzenie kwestii narodowej w Galicji

\footnotetext{
30 Ibidem, арк. 736.

31 Ibidem, спр. 35, арк. 856.

32 Ibidem, спр. 34, арк. 738.
} 
(wybory 1897 r., a z czasem problem uniwersytetu ukraińskiego i strajki rolne 1902 r.), na ziemiach czeskich problem językowy, w Krainie niechęć Niemców austriackich do dopuszczenia wykładów w języku słoweńskim w gimnazjum cylejskim szystko to stanowiło symptom jednego ogólnego problemu narodowego w monarchii habsburskiej. To jednak czesko-niemiecka rywalizacja na forum parlamentu w latach 1897-1900 wywołała kryzys o wiele większy od wymienionych konfliktów. W takich warunkach cała kadencja parlamentarna przekształciła się w niekończącą się obstrukcję i próby jej przezwyciężenia ${ }^{33}$. Na stronach „Wspomnień...” Barwiński narzekał niejednokrotnie na tę sytuację:

Niemiecko-czeska sprzeczka narodowo-polityczna i wydane przez hrabiego Badeniego regulaminy językowe dla Czech i Moraw doprowadziły w Radzie Państwa do jej obstrukcji najpierw przez posłów niemieckich, potem czeskich, a w końcu w ogóle pozbawiły austriacki parlament zdolności prawodawczej. Przez cztery lata nie udawało się uwolnić Rady Państwa z tego ,zaklętego koła”, w wyniku czego najbardziej ucierpiały inne słowiańskie narody w Austrii, takie jak ukraiński, słoweński i chorwacki, których przedstawiciele byli zjednoczeni w Słowiańskim Związku Chrześcijańsko-Ludowym, bo wszystkie ich sprawy i postulaty sprzeczka ta i obstrukcja odrzuciła na drugie miejsce ${ }^{34}$.

Cytowany fragment pamiętników obrazuje sytuację, w której Barwińskiemu i jego towarzyszom z frakcji przyszło zmagać się o wcielenie swoich postulatów programowych, przede wszystkim narodowych. Wymownym przykładem jest fakt, że w ciągu tej kadencji Rady Państwa odbyło się naraz pięć zmian na stanowisku premiera Przedlitawii ${ }^{35}$. Mimo nieprzychylnej sytuacji frakcja SZChL, aż do rozwiązania parlamentu w 1900 roku, starała się za pomocą większości parlamentarnej, a niekiedy i wbrew jej, wykorzystać swoją pozycję w izbie posłów i domagała się zmian korzystnych dla reprezentowanych przez nią narodów.

Chociaż w programie SZChL koncentrowano się zarówno na problemach społeczno-ekonomicznych, jak i narodowych, to jednak rozwój wydarzeń w parlamencie wyniósł ostatni problem na pierwsze miejsce. $Z$ tego powodu główne wysiłki posłów frakcji były nakierowane najpierw na ten aspekt. Przedstawiciele ukraińsko-słoweńsko-chorwackiego klubu pozytywnie ocenili rozporządzenia językowe Kazimierza Badeniego, co ogłosił w parlamencie Ivan Šušteršič ${ }^{36}$. Barwiński twierdził, że krok ten będzie początkiem procesu osiągania równouprawnienia przez wszystkie narody państwa. Zresztą zaostrzenie stosunków niemiecko-czeskich doprowadziło do wspomnianej w cytowanym powyżej fragmencie sytuacji, kiedy to kolejne rządy, czasem bardzo krótko istniejące, interesowały się tylko rozwiązaniem tego konfliktu przez rozstrzygnięcie problemu równoprawności narodowej na ziemiach czeskich. Problemu zaprowadzania ogólnych dla całej Przedlitawii zmian w zakresie

33 Więcej o ogólnych tendencjach narodowo-politycznych zob. W. Łazuga, Kalkulować... Polacy na szczytach C. K. Monarchii, Poznań 2013.

34 ІЛ НАН, ф. 135, спр. 41: О.Г. Барвінсь кий, Спомини з мого життя, ч. 7, 3. 40, арк. 777.

35 Do 28 XI 1897 - Kazimierz Badeni; 30 XI 1897-5 III 1898 - Paul Gautsch; 5 III 1898-2 X 1899 - Franz von Thun; 2 X 1899-21 XII 1899 - Manfred Clari-Aldringen; 21 XII 1899-18 I 1900 - Henryk Wittek; od 19 I 1900 - Ernst Koerber.

36 ІЛ НАН, ф. 135, спр. 34, арк. 775. 
równouprawnienia narodowego realnie nie rozpatrywał ani żaden z rządów, ani czołowych stronnictw na prawicy. W szeroko cytowanych na stronach „Wspomnień...” protokołach obrad SZChL jednym z kluczowych tematów był właśnie problem faktycznej drugorzędności żądań narodowych frakcji. W szczególności w trakcie obrad parlamentarnych w dniu 28 kwietnia 1899 roku słoweński poseł Ferjanćić, składając sprawozdanie o przebiegu prac komitetu wykonawczego parlamentarnej większości przy współudziale premiera Franza von Thuna, zwrócił uwagę, że wśród członków prawicy dominuje pragnienie rozwiązania zagadnienia językowego wyłącznie w Czechach i na Morawach ${ }^{37}$. Barwiński relacjonował w swoich wspomnieniach, iż odbył wówczas rozmowę z Thunem, któremu zwracał uwagę na potrzebę rozwiązania kwestii narodowej w całej Przedlitawii jednocześnie. Znacząca była odpowiedź premiera, który otwarcie przyznał się, że nie wiedział wprawdzie nic o sytuacji w Galicji, wyraził przy tym przekonanie, że jest ona lepsza niż w Czechach. Takie słowa wywoływały aprobatę polskiego posła Stanisława Madejskiego, natomiast Barwiński bezskutecznie przekonywał przewodniczącego rządu o błędności takiego poglądu ${ }^{38}$.

Przypomnienie Madejskiego przez Barwińskiego nie było przypadkowe. Z punktu widzenia obrony interesów ukraińskich w parlamencie (jak upatrywał je lider konserwatystów ukraińskich) największy problem stanowiło Koło Polskie. Sednem tego problemu było to, że mimo wspólnego partycypowania w koalicji parlamentarnej, interesy Ukraińców i Polaków często istotnie się różniły, a niekiedy były wprost sprzeczne. Barwiński przypominał we wspomnieniach różne przykłady, wśród których dwa szczególnie zwracają uwagę. Pierwszy dotyczył różnej wizji dróg rozwiązania kwestii narodowej. Jeśli SZChL nalegał, że Rada Państwa, a w szczególności rządząca akurat prawica, musi ją uregulować, to polscy politycy pragnęli rozpatrywać ten problem na poziomie sejmów krajowych z jednoczesnym rozszerzeniem kompetencji tych ostatnich ${ }^{39}$. Drugi przykład to historia projektu ustawy językowej autorstwa polskiego posła, przyszłego wspólnego ministra skarbu Austro-Węgier, Leona Bilińskiego, przygotowanego jesienią 1899 roku. W pamiętnikach Barwiński zaznaczał, że ten projekt ustawy, mimo nielicznych usterek, w ówczesnych okolicznościach był optymalny ${ }^{40}$. Zresztą projekt ten nie został przedstawiony na forum izby posłów z powodu wysiłków przewodniczącego Koła Polskiego Apolinarego Jaworskiego, rozdrażnionego przygotowaniem takiego dokumentu bez jego zawiadomienia ${ }^{41}$. We „Wspomnieniach...” Barwiński zacytował fragment pamiętników Bilińskiego, w których polski polityk miał zinterpretować odrzucenie tego projektu jako utratę szansy na lepsze losy monarchii Habsburgów już w czasach I wojny światowej i na zdobycie wówczas przychylności dla sprawy polskiej Czechów, Słoweńców, „może nawet i Rusinów"42. Przy tej okazji Barwiński, oczywiście z uwzględnieniem własnego punktu widzenia na wydarzenia polsko-ukraińskiej wojny w Galicji Wschodniej

\footnotetext{
37 Ibidem, спр. 38: О.Г. Барвінський, Спомини $з$ мого життя, ч. 7, 3. 37, арк. 339.

38 Ibidem.

39 Ibidem, арк. 338.

40 Ibidem, спр. 34, арк. 772/1.

41 Ibidem, арк. 772/1-772/2.

42 Cyt. za: ibidem, арк. 772/2.
} 
i polskiej polityki w pierwszych latach po jej zakończeniu, wymienił Leona Bilińskiego, a także Michała Bobrzyńskiego jako polskich polityków z szerokim światopoglądem, których polityka, jego zdaniem, mogła doprowadzić do znacznie lepszych stosunków polsko-ukraińskich już po rozpadzie państwa austro-węgierskiego ${ }^{43}$.

Mniej uwagi w kontekście kwestii narodowej i działalności SZChL Barwiński w pamiętnikach poświęcił problemom Słoweńców i Chorwatów. Zresztą nawet te istniejące wzmianki we wspomnieniach polityka świadczą, że polsko-ukraińskie nieporozumienia w znacznej mierze były analogiczne do stosunków słoweńsko-niemieckich i chorwacko-włoskich, co zasadniczo negatywnie oddziaływało na atmosferę w koalicji parlamentarnej:

Wśród tych okoliczności wydział wykonawczy większości parlamentarnej (prawicy) zamierzał
stworzyć ogólny program prawicy, jednak te zamiary pozostały bezskutecznymi. Polacy
bronili swojego stanu posiadania w Galicji, wobec czego posłowie ruscy domagali się rów-
nouprawnienia narodowo-politycznego, a również Słoweńcy i Chorwaci występowali przeciw
próbom dominacji Niemców i Włochów w południowo-zachodnich krajach austriackich.
„Słowiański Związek chrześcijański-narodowy” pragnął zredagowania ogólnego państwowego
prawa językowego, żeby tym sposobem zabezpieczyć językowe i narodowe prawa narodu
ukraińskiego i Słowian południowych, jednak wszystkie te usiłowania uległy rozbiciu przez
opór Polaków ${ }^{44}$.

Przytoczone we „Wspomnieniach...” protokoły pozwalają śledzić narastające niezadowolenie w SZChL, ponieważ nie tylko projektem zaprowadzenia ogólnego równouprawnienia narodowego nie zajęła się prawica ani rząd, ale także odrębnymi postulatami Ukraińców, Słoweńców i Chorwatów w koalicji rządowej się nie zajmowano lub zwlekano z wprowadzeniem już podjętych decyzji. Na przykład w 1899 roku Słoweńcy, zgodnie z uchwałą Sejmu Krainy i przy wsparciu reszty frakcji, domagali się od rządu Franza von Thuna stworzenia uniwersytetu w Lublanie albo przynajmniej cesarskiego i rządowego zobowiązania co do zorganizowania takiej instytucji w najbliższej przyszłości. Zresztą, mimo obietnic prezydenta ministrów Przedlitawii co do zwiększenia liczby stypendiów naukowych dla Słoweńców, nie zostały one zrealizowane. Słoweńcy nie doczekali się również utworzenia filii Wyższego Sądu Krajowego w stolicy Krainy ${ }^{45}$. Ukraińska część SZChL w latach 18971900 zwracała natomiast uwagę na ignorowanie przez rząd już istniejących norm albo uchwalonych przez Sejm Galicyjski decyzji, przede wszystkim w stosunku do sytuacji językowej i założenia gimnazjum ukraińskiego w Tarnopolu ${ }^{46}$. Trochę lepsza była sytuacja chorwacka. Wraz z objęciem teki premiera przez Ernesta von Koerbera, na początku 1900 roku, udało się zainicjować rozwój sieci kolejowej w Dalmacji.

43 Ibidem.

44 Ibidem, спр. 35, арк. 1002-1003. Ten przypadek ukazuje charakterystyczny problem współczesnego konserwatyzmu ukraińskiego w Galicji, w szczególności sytuację Ołeksandra Barwińskiego - dla wcielenia swoich zasad i idei musiał faktycznie przeciwstawić się istniejącemu status quo - polskiej dominacji w Galicji. M. Mudryj, Kwestia tożsamości wśród ruskich elit politycznych w Galicji, „Prace Historyczne" 2017, t. 144, z. 2: Kształty galicyjskich tożsamości, red. A. Świątek, s. 255-275.

45 ІЛ НАН: ф. 135, спр. 38, арк. 347-348, 351-353.

46 Ibidem, арк. 341. 
Jego rząd próbował dużymi projektami infrastrukturalnymi odwrócić uwagę od problemu narodowego.

Ze względu na taką sytuację na porządku dziennym SZChL było pytanie o celowość dalszego pozostawania w składzie większości parlamentarnej, a więc i wsparcia rządów, zwłaszcza Franza von Thuna, który w swojej polityce chciał opierać się właśnie na prawicy. Najostrzejsza dyskusja odbyła się jesienią 1898 roku. Prawie równocześnie odbyły się zjazdy: polityków słoweńskich w Lublanie (22 września) i ukraińskich posłów Sejmu Krajowego galicyjskiego oraz Rady Państwa w Stanisławowie (23 września). Na obu spotkaniach skrytykowano stosunek koalicji i rządu do słoweńskich i ukraińskich potrzeb narodowych ${ }^{47}$. Ponadto Słoweńcy zadecydowali o wyjściu z większości parlamentarnej, aczkolwiek ostatecznie nie wcielili tego kroku w życie ${ }^{48}$. Wydarzenia te poważnie zaniepokoiły prawicę, rząd i Thuna, ponieważ stanowiły zagrożenie zarówno dla większości parlamentarnej, jak i dla pozycji premiera, który wszystkimi siłami starał się przełamać kryzys polityczny w Przedlitawii. Barwiński wspominał: „Rząd jest zaniepokojony naszą uchwałą stanisławowską i hrabia Thun wczoraj mnie pociągnął za rękę, żeby jemu wyjaśnił [sytuację]"49.

Innym środkiem wywierania przez SZChL presji na rząd były groźby niegłosowania za rządowymi projektami ustaw, w pierwszej kolejności za nową ekonomiczną ugodą austro-węgierską i budżetem państwowym. Sytuacja zaostrzyła się na tyle, że sam cesarz Franciszek Józef na audiencji przyzywał lidera Słoweńców Franza Povśe, aby wypełnił swój patriotyczny obowiązek i, mimo wszystko, poparł kluczowe dla państwa projekty ${ }^{50}$. Zresztą po dyskusjach wewnątrz frakcji SZChL 20 głosami przeciw 8 zdecydował o pozostaniu w składzie prawicy z zastrzeżeniem o ponownym rozpatrzeniu swojego związku z koalicją w razie dalszego ignorowania żądań frakcji ${ }^{51}$. Głównym argumentem, który przemawiał na rzecz trwania w koalicji był brak perspektyw w przypadku przejścia do opozycji, w której byli austriaccy liberałowie-centraliści, socjaliści oraz „wszechniemcy” Schönerera, co oznaczało o wiele mniejsze korzyści niż problematyczny pobyt w konserwatywnej większości parlamentarnej. Barwiński przywoływał jeszcze opinie słoweńskich posłów Šukljego i Kreka, że rozpad większości parlamentarnej z winy Ukraińców i południowych Słowian ich oponenci wykorzystywaliby jako argument o niezdolności tych narodów do działalności państwowej ${ }^{52}$.

Ołeksandr Barwiński wspominał również inne przykłady niezgody w łonie prawicy. W szczególności, jeszcze jesienią 1897 roku, kiedy obstrukcja niemiecka zupełnie sparaliżowała parlament, komitet wykonawczy prawicy większością głosów i wbrew stanowisku SZChL przyjął tak zwane Lex Falkenhayn - poprawki do regulaminu działalności izby posłów. Pozwalały one przewodniczącemu parlamentu na $30 \mathrm{dni}$ wykluczać posłów utrudniających normalną pracę Rady Państwa, a w razie oporu -

\footnotetext{
47 Ibidem, спр. 37: О.Г. Барвінський, Спомини з мого життя, ч. 7, з. 36, арк. 111-112.

48 Ibidem.

49 Ibidem, арк. 116.

50 Ibidem, спр. 38, арк. 370.

51 Ibidem, арк. 343.

52 Ibidem, арк. 342.
} 
wezwać policję celem usunięcia tych posłów z izby poselskiej. Według ukraińskich, słoweńskich i chorwackich konserwatystów takie działanie mogło prowadzić tylko do pogorszenia sytuacji ${ }^{53}$.

Mimo częstych różnic zdań między partnerami w koalicji i rządzie Barwiński nigdy w swoich pamiętnikach nie podał w wątpliwość słuszności decyzji o utworzeniu SZChL i uczestnictwie w większości parlamentarnej. Twierdził, że mimo wszystkich problemów partnerstwo to było znacznie korzystniejsze dla społeczeństwa ukraińskiego w Galicji niż polityka opozycyjna trzech ukraińskich posłów z IX kadencji (1897-1900). Wśród osiągnięć frakcji i własnych Barwiński wymieniał utworzenie Katedry Języka i Literatury Staroukraińskiej na Uniwersytecie Lwowskim, zapoczątkowanie wydawania „Zwiastuna ustaw państwowych” w zapisie fonetycznym języka ukraińskiego zamiast $\mathrm{w}$ rusofilskim jazycziju, ustanowienie stypendiów naukowych dla badaczy ukraińskich, zwiększenie liczby szkół. Na pierwszym miejscu stawiał zaś doprowadzenie do otwarcia w październiku 1898 roku gimnazjum ukraińskiego im. Franciszka Józefa w Tarnopolu. Decyzja o jego założeniu została podjęta najpierw przez Sejm Krajowy we Lwowie, lecz realizacja tego postanowienia zatrzymała się z powodu zwłoki ministerstwa wyznań i oświaty, w szczególności ministra Artura Bylandta-Rheidta. Było to zaledwie parę dni po ostrej dyskusji w SZChL o celowości dalszej współpracy z większością parlamentarną, dlatego Barwiński wykorzystał okazję i zagroził Franzowi Thunowi, że jeżeli gimnazjum ukraińskie w Tarnopolu nie zostanie utworzone natychmiast, to SZChL porzuci koalicję i zburzy zarówno większość w Radzie Państwa, jak i pozycję rządu. Taka kategoryczność postawiła w sytuacji bez wyjścia ministra oświaty oraz ministra dla Galicji Adama Jędrzejowicza, bez akceptacji którego takiej decyzji nie można było urzeczywistnić. Wynikiem skonsolidowanego wsparcia Słoweńców i Chorwatów stało się wydanie przez ministra oświaty koniecznych rozporządzeń i 14 października 1898 roku tarnopolskie gimnazjum został uroczyście otworzone ${ }^{54}$.

Ze względu na taką ocenę działalności wspólnej konserwatywnej frakcji nie dziwi, że kiedy prawica rozpadła się przez przejście młodoczechów (największej czeskiej frakcji) do obstrukcji i Rada Państwa latem 1900 roku została rozwiązana, Barwiński, obroniwszy swój mandat, życzył sobie przedłużyć tę współpracę po nowych wyborach. Doprowadziło to do utworzenia faktycznego następcy SZChL - frakcji Centrum Słowiańskie. Tym razem sytuacja parlamentarna od samego początku była o wiele mniej sprzyjająca niż wiosną 1897 roku. Nowo wybrany parlament był jeszcze bardziej podzielony na grupy niż poprzedni (aż 20 klubow) $)^{55}$, a grupa konserwatywnych ukraińskich posłów teraz nie była większością pośród ogółu przedstawicielstwa ukraińskiego. Zwolennicy Barwińskiego utworzyli Klub Rusko-Ludowy liczący pięć osób $^{56}$, a ich przeciwnicy, na czele z Julijanem Romanczukiem, powołali liczący taką samą liczbę posłów Klub Ruski. Również między Słoweńcami i Chorwatami doszło

53 Ibidem, спр. 34, арк. 801.

54 Ibidem, спр. 37, арк. 128-134.

55 „Gazeta Narodowa”, 2 III 1901, nr 61.

56 Z poprzedniej kadencji, oprócz Barwińskiego, pozostali Mandyczewski i Emilian Hładyszowski, który w 1899 r. zamienił o. Grobelskiego. Do nich dołączyli z Galicji jeszcze Iwan Dłużański 
do podziałów. Ci ostatni utworzyli własny klub, do którego dołączyło pięciu słoweńskich posłów (Klub Słoweńsko-Chorwacki) ${ }^{57}$. Większość Słoweńców z Šušteršičem na czele ( 9 osób) razem z grupą Barwińskiego i dwoma morawskimi katolickimi politykami utworzyli natomiast Centrum Słowiańskie. Latem 1902 roku grupa ta uformowała się ostatecznie po zjednoczeniu z Klubem Słoweńsko-Chorwackim. Ogólna liczebność frakcji wynosiła wówczas 27 członków (10 Słoweńców, 10 Chorwatów, 5 Ukraińców, 2 Czechów). Swoje położenie w takim związku Barwiński uważał za znacznie lepsze niż pięciu opozycyjnych posłów ukraińskich, którzy nadal pozostawali oddzielnym klubem ${ }^{58}$.

Działalność Centrum Słowiańskiego została naświetlona we „Wspomnieniach...” słabiej niż działalność SZChL. Barwiński krótko scharakteryzował motywy nawiązania współpracy, które w znacznej mierze były powieleniem tych z 1897 roku. Ponownie akcentował znaczenie dyscypliny i organizacji we frakcji dla kultury politycznej posłów ukraińskich. W swoich pamiętnikach autor więcej natomiast uwagi poświęcił stosunkom z drugą frakcją ukraińską, z którą stosunki były napięte. Przedstawiciel opozycyjnego Klubu Ruskiego Andrij Kos na posiedzeniu Rady Państwa w dniu 14 lutego 1901 roku miał oświadczyć: „My [Klub Ruski] mamy wszystkich Rusinów za sobą, lecz za tamtymi panami Barwińskim i kompanią nie stoi żaden z Rusinów!.. Panowie ci nie mają prawa mówić imieniem narodu ruskiego, bo naród ruski reprezentujemy my"59. Taki stosunek do Barwińskiego był typowy nie tylko dla opozycyjnych posłów ukraińskich, ale i dla większości społeczeństwa ukraińskiego z czasów rozłamu narodowców ukraińskich. Lidera ukraińskiego ruchu chrześcijańsko-społecznego stale prześladowały oskarżenia o zdradę interesów Ukraińców na korzyść Polaków oraz o ugodowość. W warunkach zaostrzenia ukraińsko-polskich stosunków w Galicji na początku XX wieku padały na urodzajny grunt, a realna polityka Barwińskiego miała coraz mniej sympatyków. Ze względu na to nie dziwi fakt, że zjednoczenie grupy konserwatystów ukraińskich w parlamencie ze Słoweńcami i Chorwatami, a nie innymi posłami ukraińskimi, zarówno w latach 1897-1900, jak i w następnej kadencji, spotkało się z niezrozumieniem i krytyką. Zarzucono Barwińskiemu brak solidarności z Ukraińcami i apelowano, by porzucił Centrum Słowiańskie i dołączył do klubu Romanczuka.

Znamienny jest list z 15 marca 1904 roku do Barwińskiego od jego dawnego towarzysza, znanego fizyka, Iwana Puluja, w którym bezwzględnie krytykował on politykę kolegi, który „,przyzwyczaił się chylić się przed ministrami” i, według autora listu, to właśnie on, a nie kto inny, miał być winny rozłamowi wśród Ukraińców w parlamencie. List kończył się apelem, by „pójjść do Canossy” - zerwać związek ze Słoweńcami i Chorwatami oraz połączyć się z towarzyszami w Klubie Ruskim ${ }^{60}$. Nie mniej wymowna była też odpowiedź Barwińskiego:

\footnotetext{
i przedstawiciel Bukowiny Jerotej Pihuliak. ІЛ НАН, ф. 135, спр. 42: О.Г. Барвінський, Спомини 3 мого життя, ч. 8, з. 41, арк. 20.

57 Ibidem, арк. 80.

58 Ibidem, спр. 45: О.Г. Барвінський, Спомини з мого життя, ч. 8, з. 44, арк. 494-495.

59 Ibidem, спр, 42, арк. 44-45.

60 Ibidem, спр. 47: О.Г. Барвін ський, Спомини з мого життя, ч. 9, 3. 46, арк. 297/5-297/11.
} 
W niektórych sprawach skomplikowanych stał się dla nas Związek [Centrum] Słowiański wielce korzystny, ponieważ w parlamencie decyduje liczba głosów. [...] byłbym za jednością [z Romanczukiem], tak samo i moi towarzysze, życzymy sobie tylko znaleźć taką formę, która nie rozrywałaby naszego kontaktu ze Związkiem Słowiańskim, który zawsze gościnnie podtrzymuje nie tylko nasze starania, ale także często starania, projekty i interpelacje klubu Romanczuka ${ }^{61}$.

Chociaż Barwiński nie pisał o tym otwarcie, to ze stronic pamiętników wynika wyraźnie, że w 1904 roku znalazł się w sytuacji beznadziejnej. Uważając współpracę w ramach Centrum Słowiańskiego za optymalny wariant ze względu na większą liczbę głosów oraz dostęp do komisji parlamentarnych, zetknął się on z przedłużającą niezdolnością Rady Państwa do aktywnej pracy parlamentarnej, co niwelowało korzyści, jakie dawał udział w koalicji. Głównym jednak problemem okazała się utrata własnych wpływów wśród społeczności ukraińskiej. Namiestnik Galicji, którym był od 1898 roku Leon Piniński, odstąpił od praktyk poprzedników - to jest Kazimierza Badeniego i Eustachego Sanguszki - i zaczął wspierać nie umiarkowanych konserwatystów narodowców z Barwińskim na czele, a rusofilów. Sprawiło to, że polityczne perspektywy Barwińskiego okazały się zupełnie mgliste. Ze względu na te fakty, jak i na narastanie problemów w relacjach ukraińsko-polskich, lider ruchu chrześcijańsko-społecznego zmienił częściowo swoją politykę na bardziej opozycyjną w stosunku do polskich elit w Galicji. W 1904 roku już po raz drugi wziął udział w secesji Ukraińców w Sejmie Galicyjskim na znak protestu przeciw odrzucaniu przez polską większość projektu utworzenia gimnazjum ukraińskiego w Stanisławowie. Na dodatek przegrał uzupełniające wybory z rusofilskim kandydatem, którego podtrzymywał wpływowy polski polityk Tadeusz Cieński, przez co utracił mandat w Sejmie Krajowym, w którym obradował przez 10 lat ${ }^{62}$.

$\mathrm{Na}$ zjeździe ukraińskich posłów Rady Państwa i Sejmu Krajowego, który odbył się we Lwowie w dniu 15 sierpnia 1904 roku, Barwiński znalazł się pod presją większości obecnych, by porzucić Centrum Słowiańskie i połączyć się z Klubem Ruskim. Nawet Jerotej Pihuljak, który do ostatniego momentu akcentował niedocenienie przez społeczeństwo ukraińskie korzyści płynącej ze współpracy ze Słoweńcami i Chorwatami, w końcu poparł ideę jedności z pozostałymi posłami ukraińskimi ${ }^{63}$. W takich okolicznościach Barwiński nie miał innego wyjścia. Jak pisał:

Po zakończeniu dyskusji podczas przerwy przed głosowaniem posłowie Stocki, Pihuljak i Wasylko zwrócili się do mnie i prosili, żebym nie oponował przeciw zjednoczeniu. Oświadczyłem na to, iż na dowód, że nie kieruję się ambicją osobistą albo innymi wysuniętymi przeciw mnie motywami, zgodzę się na to i przeprowadzę to również w Związku Słowiańskim, lecz biorę Was za świadków, że Klub Ruski i Komitet Ludowy ${ }^{64}$ nie wyciągną z tego wydarzenia potrzeb-

61 Ibidem, арк. 297/20-297/22.

62 О. Аркуша, Украӥнський християнсько-суспільний рух у Галичині на початку ХХ століття. Політичне товариство „Руська громада” [w:] Шляхами історії. Науковий збірник історичного факультету ЛНУ ім. Івана Франка. На пошану професора Костянтина Кондратюка, упор. О. Сухий, Львів 2004, s. 63-99.

63 ІЛ НАН, ф. 135, спр. 48: О.Г. Барвін сь кй, Спомини з мого життя, ч. 9, 3. 47, арк. 468.

64 Kierowniczy organ największej i bardzo wpływowej w Galicji Ukraińskiej Partii Narodowo-Demokratycznej. 
nych wniosków, bo im rozchodzi się tylko o to, żeby odciągnąć nas od Związku, z którego pomocą niejedno osiągnęliśmy dla naszego narodu ${ }^{65}$.

W wyniku tej decyzji, na najbliższej sesji Rady Państwa ukraińscy członkowie Centrum Słowiańskiego porzucili frakcję, co położyło kres ścisłej współpracy ukraińskich, słoweńskich i chorwackich konserwatywnych katolickich polityków w ławach parlamentu wiedeńskiego. Po przyłączeniu do Klubu Ruskiego Barwiński nie odgrywał już w nim tak istotnej roli, jak we wspólnych frakcjach słowiańskich, a jego nadzieje na wzmocnienie własnej pozycji przez oddalenie oskarżeń o niesolidarność nie ziściły się. Zarzuty stawiane mu na temat jego ugodowości wystarczały, by pogrzebać jego szanse wyborcze. W kolejnych wyborach do Rady Państwa w 1907 roku, które odbywały się już na zasadzie powszechnego i tajnego prawa wyborczego, nawet nie zgłosił swojej kandydatury ${ }^{66}$.

Oprócz politycznych procesów wspomnienia Ołeksandra Barwińskiego ujawniają jeszcze jeden ważny aspekt współpracy ukraińskich, słoweńskich i chorwackich konserwatystów w wiedeńskiej Radzie Państwa na przełomie XIX i XX wieku zrozumienie przez nich pojęcia wzajemności słowiańskiej i jej pozaparlamentarnego oraz indywidualnego wymiaru. Dla Barwińskiego nie do przyjęcia była każda idea, która zaprzeczała albo choćby częściowo podawała w wątpliwość pełną odrębność narodu ukraińskiego. Z tego powodu całkowicie negatywnie postrzegał zarówno koncepcje rusofilów, jak i przejawy panslawizmu. Jednocześnie opisana w pamiętnikach działalność pokazała, że jedność słowiańska nie była dla Barwińskiego pustym pojęciem. Rozumiał ją jako obopólnie korzystną współpracę dla rozwoju narodowego odrębnych od siebie narodów słowiańskich. W swojej działalności politycznej przede wszystkim zabiegał o osiągnięcie pełnego równouprawnienia narodowego w Przedlitawii. Realizacji tego celu miały służyć SZChL czy Centrum Słowiańskie ${ }^{67}$.

Jednocześnie wspólna działalność ukraińskich, słoweńskich i chorwackich konserwatystów sprzyjała ogólnemu umocnieniu związków i trwałym kontaktom między przedstawicielami narodów reprezentowanych przez oba kluby, których losy w państwie austriackim - jak się okazało - miały sporo wspólnego. Barwiński wspominał, jak został zaproszony na wszechsłoweńskie i chorwackie zebranie do Lublany w 1897 roku, gdzie został wybrany przewodniczącym i wygłosił część swojego przemówienia w języku słoweńskim ${ }^{68}$. Słoweńskie Towarzystwo Katolicko-Polityczne wysłało mu w tym samym roku podziękowanie za działalność w SZChL ${ }^{69}$. W Wiedniu zaproszono również Barwińskiego na przeniesienie szczątków Jerneja Kopitara i Vuka Karadžicia $^{70}$. Rola współpracy w nawiązywaniu osobistych kontaktów i ,prawdziwej

65 ІЛ НАН, ф. 135, спр. 48, арк. 469-470.

66 Р. Лехнюк, На порозі модерного світу..., s. 150-152.

67 Центральний державний історичний архів України, м. Львів, ф. 818: А. Вахнянин, п. 1, спр. 10: Протоколи засідань „Руського клубу” державної ради, писані Вахнянином А., 1891-1902, арк. 68.

68 Ibidem, спр. 35, арк. 823-824.

69 Ibidem, арк. 864-868.

70 Ibidem, арк. 870-872. 
wzajemności słowiańskiej”, jak nieraz określał w swoich pamiętnikach te stosunki Barwiński, również była istotna:

Tamtym sposobem, znajomością obopólną, wzmacniały się stosunki między ruskimi i południowosłowiańskimi [posłami] oraz Czechami [...]. Budziła się i pogłębiała się prawdziwa wzajemność słowiańska. Oni zaczęli rozumieć nasze sprawy i pragnienia, a my ich, tak że uważali oni nasze sprawy za swoje, a my ich za nasze. Zawiązywała się przyjaźń osobista między nami. [...] Również podczas sesji Rady Państwa żyliśmy zgodnie i przyjaźnie z posłami południowosłowiańskimi i czeskimi nie tylko w parlamencie, w klubie, ale i poza nim¹

Najsilniejsze przyjacielskie stosunki Barwiński zawiązał z wieloletnim liderem słoweńskiego ruchu katolickiego Ivanem Šušteršičem, a także z czeskim działaczem Antonínem Cirilem Stojanem, z którym korespondencję lider konserwatystów ukraińskich podtrzymywał do samej śmierci kolegi w 1923 roku.

Nieopublikowane „Wspomnienia z mojego życia” Ołeksandra Barwińskiego ujawniają przed badaczami wiele aspektów współpracy Ukraińców, Słoweńców i Chorwatów na forum Rady Państwa w latach 1897-1904. W pamiętnikach Barwiński dokładnie naświetlił motywy własnej aktywności i oczekiwań wobec takiego partnerstwa, przedstawił ideowe zasady, działalność, funkcjonowanie wspólnych frakcji, zwłaszcza SZChL. Informacje te naturalnie mieszczą się w szerszym kontekście procesów społeczno-politycznych zarówno w Galicji, jak i w całej monarchii Habsburgów. Pozwala to lepiej zrozumieć sukcesy, a tym bardziej niepowodzenia tego partnerstwa.

Jednocześnie należy pamiętać, że pamiętniki te, jak i prawie wszystkie inne źródła tego rodzaju, stanowią subiektywny przekaz autora. Oczywiście, że „Wspomnienia..." ujawniają najpierw perspektywę ukraińską wspólnej działalności Ukraińców, Słoweńców i Chorwatów w Radzie Państwa, a problemy partnerów we frakcjach SZChL i Centrum Słowiańskiego oraz ich wizje tej współpracy naświetlone zostały fragmentarycznie. Na kształcie „Wspomnień...” Barwińskiego zaważyły dawne konflikty, których w trakcie jego kariery politycznej było niemało. Lider ukraińskiego ruchu chrześcijańsko-społecznego nie wątpił w celowość współpracy ze Słoweńcami i Chorwatami, i miał do tego podstawy. Równocześnie krytyka sojuszu frakcji słowiańskich przez opozycję ukraińską nie zawsze była tylko skutkiem błędnych informacji, co Barwiński zarzucał Pulujowi, bywała też uzasadniona.

Chociaż lider konserwatystów ukraińskich tego nie akcentował, to z jego pamiętników wyraźnie wybrzmiewa niedostateczna aktywność pozostałych przedstawicieli ukraińskich w SZChL i w Centrum Słowiańskim - w rzeczywistości całą pracę wykonywał sam Barwiński, a tylko w czasie istnienia SZChL również Anatol Wachnianyn. Aktywność innych ukraińskich członków tejże frakcji była natomiast sporadyczna, co obniżało ogólną efektywność całego obozu. Również w analizowanych w niniejszym artykule fragmentach ,Wspomnień...” można dostrzec, że autor częściowo przemilczał stopniowy spadek swoich wpływów, co wynikało z wymienionych powyżej przyczyn.

71 Ibidem, арк. 825-826. 
Zresztą subiektywność autora „Wspomnień...” wyrażała się w jego emocjonalnych ocenach. W kontekście badanego tematu największy żal i rozczarowanie Barwińskiego wywoływało niedocenienie przez większość polityków i całe społeczeństwo ukraińskie w Galicji doniosłości członkostwa posłów w SZChL i Centrum Słowiańskim ${ }^{72}$. Jednocześnie typowo konserwatywny i niepozbawiony racji był jego pogląd na problem braku odpowiedniego stopnia kultury i doświadczenia politycznego galicyjskich Ukraińców. Pisał:

Tu [w składzie SZChL i koalicji parlamentarnej] przechodziliśmy prawdziwą szkołę polityczną, której brakowało Rusinom, bo u nas zdawało się każdemu, że rodzi się politykiem, a już absolwent gimnazjum albo słuchacz uniwersytetu uważał się za powołanego do rozwiązania dalekosiężnych i trudnych zagadnień polityczno-narodowych i społecznych ${ }^{73}$.

Mimo niewątpliwej subiektywności przekazu „Wspomnienia z mojego życia” Ołeksandra Barwińskiego pozostają najważniejszym źródłem wiedzy historycznej, bez którego niemożliwe byłoby gruntowne rozpatrzenie dzisiaj mało znanego wątku współpracy słowiańskiej w ramach monarchii Habsburgów.

\section{BIBLIOGRAFIA}

\section{Źródła}

\section{Źródta archiwalne}

Інститут літератури ім. Т.Г. Шевченка НАН України, Відділ рукописних фондів і текстології, м. Київ (ІЛ НАН)

ф. 135: Барвінський О.Г.,

спр. 30: О.Г. Барвінський, Спомини з мого життя, ч. 6, з. 29.

спр. 34: О.Г. Барвінський, Спомини з мого життя, ч. 6, з. 33.

спр. 35: О.Г. Барвінський, Спомини з мого життя, ч. 6, з. 34.

спр. 37: О.Г. Барвінський, Спомини з мого життя, ч. 7, з. 36.

спр. 38: О.Г. Барвінськкий, Спомини з мого життя, ч. 7, з. 37.

спр. 41: О.Г. Барвінськкий, Спомини з мого життя, ч. 7, з. 40.

спр. 42: О.Г. Барвінський, Спомини з мого життя, ч. 8, з. 41.

спр. 45: О.Г. Барвінський, Спомини з мого життя, ч. 8, з. 44.

спр. 47: О.Г. Барвінський, Спомини з мого життя, ч. 9, з. 46.

спр. 48: О.Г. Барвінський, Спомини з мого життя, ч. 9, з. 47.

Львівська національна наукова бібліотека ім. В. Стефаника (ЛННБУ)

ф. 11: Барвінський,

спр. 5387, п. 332. арк. 1-2: Виступ О. Барвінського на довірочних зборах товариства „Руська Громада” у Львові, 1903 р.

\footnotetext{
72 Ibidem, спр. 34, арк. 741.
}

73 Ibidem, арк. 764-765. 
Центральний державний історичний архів України, м. Львів ф. 818: Вахнянин Анатоль,

оп. 1, спр. 10: Протоколи засідань „Руського клубу” державної ради, писані Вахнянином А., 1891-1902.

Źródła drukowane

О. Барвінський, Спомини з мого життя, т. 1, упор. А. Шацька, О. Федорук, ред. Л. Винар, І. Гирич, Київ 2004.

Наші християнські суспільники, Львів 1910.

Prasa

„Gazeta Narodowa” (Lwów) 1901.

„Руслан” (Львів) 1897.

\section{Opracowania}

Binder H., Galizien in Wien. Parteien, Wahlen, Fraktionen und Abgeordnete im Übergang zur Massenpolitik, Wien 2005.

Łazuga W., Kalkulować... Polacy na szczytach C. K. Monarchii, Poznań 2013.

Maciak D., Próby porozumienia polsko-ukraińskiego w Galicji w latach 1888-1895, Warszawa 2006.

Melik V., Slovenci v Državnem zboru 1893-1904, „Zgodovinski časopis”, letnik 33, 1979, št. 1. s. 49-66.

Mudryj M., Kwestia tożsamości wśród ruskich elit politycznych w Galicji, „Prace Historyczne" 2017, t. 144, z. 2: Ksztalty galicyjskich tożsamości, red. A. Świątek, s. 255-275.

Radosavljevič B., Katoliška narodna stranka in Hrvati v letih 1897-1903 , „Zgodovinski časopis", letnik 48, 1994, št. 3. s. 335-351.

Аркуша О., Барвінський Олександр Григорович [w:] Енциклопедія історії Украӥни, ред. В.А. Смолій [et al.], т. 1, Київ 2003, s. 189.

Аркуша О., Украӥнський християнсько-суспільний рух у Галичині на початку ХХ століття. Політичне товариство „Руська громада” [w:] Шляхами історії. Науковий збірник історичного факультету ЛНУ ім. Івана Франка. На пошану професора Костянтина Кондратюка, упор. О. Сухий, Львів 2004, s. 63-99.

Вендланд А.В., Русофіли Галичини. Українські консерватори між Австрією і Росією, 1818-1915, Львів 2015.

Винар Л., Гирич I., Вступне слово [w:] О. Барвінський, Спомини з мого життя, т. 1, упор. А. Шацька, О. Федорук, ред. Л. Винар, І. Гирич, Київ 2004, s. 11-14.

Кліш А., Лехнюк Р., Співпрачя слов'янських депутатів християнсько-суспільного напряму в австрійській Державній раді наприкінці XIX - на початку XX cm. (за украӥнськими джерелами) [w:] Проблеми слов'янознавства, вип. 65, Львів, 2016, s. 167-177.

Лехнюк Р., Дилеми украӥнського консерватора - приклад Олександра Барвінського [w:] Матеріали III Міжнародної науково-практичної конференції „,Тернопіль і Тернопілля в історії та культурі Украӥни і світу (від найдавніших часів до сьогодення)”, ред. І.С. Зуляк, Тернопіль 2017, s. 66-72. 
Лехнюк Р., На порозі модерного світу. Украӥнські консервативні середовища в Галичині у першій чверті ХХ століття, Львів 2019.

Чорновол I., Галицькі війни за історію, http://zbruc.eu/node/5444 (dostęp: 19 V 2019).

Чорновол І., Польсько-украӥнська угода 1890-1894 pp., Львів 2000.

Чорновол I., Тягар прагматизму, або Олександр Барвінський у світлі сучасності [w:] О. Барвінський, Спомини з мого життя, т. 1, упор. А. Шацька, О. Федорук, ред. Л. Винар, І. Гирич, Київ 2004, s. 17-35. 